\title{
STUDI EKSPLORASI SARANA DAN PRASARANA PRAKTIK PADA MATA PELAJARAN PEMELIHARAAN CHASIS DAN PEMINDAH TENAGA DI SMK
}

\author{
Deka Ariyanto $^{1}$, Ono Wiharna ${ }^{2}$, Ridwan A. M. Noor ${ }^{3}$ \\ Universitas Pendidikan Indonesia \\ Jl. Dr. Setiabudhi No. 229 Bandung 40154 \\ dekaariyanto.1993@gmail.com
}

\begin{abstract}
ABSTRAK
Idealnya proses pembelajaran di Sekolah Menengah Kejuruan mengacu pada Badan Standar Nasional Pendidikan. Kenyataannya sarana praktik di SMK Negeri 6 Bandung belum sepenuhnya memenuhi standar, terutama pada rasio jumlah sarana praktik dengan jumlah siswa. Survey awal yang dilakukan, luas area kerja kelistrikan otomotif tidak sesuai dengan standar. Penelitian ini bertujuan untuk memperoleh informasi sarana dan prasarana praktik pada Mata Pelajaran Pemeliharaan Chasis dan Pemindah Tenaga Program Studi Teknik Kendaraan Ringan di SMK Negeri 6 Bandung. Metode penelitian menggunakan metode deskriptif dengan skala persentase. Hasil penelitian menunjukkan bawha ketersediaan prasarana ruang praktik adalah 75\% (layak), sarana praktik pada area kerja pemeliharaan chasis dan pemindah tenaga 71,42\%, ketersediaan Alat pelindung Diri adalah $80 \%$ (layak), ketersediaan sarana praktik; pemeliharaan sistem kopling adalah $68,75 \%$ (layak), pemeliharaan transmisi manual adalah 43,47\% (kurang layak), pemeliharaan final drive/gardan adalah 42,85\% (kurang layak), pemeliharaan poros roda adalah 53,84\% (kurang layak), pemeliharaan sistem rem adalah 77,27\% (layak), pemeliharaan sistem kemudi adalah 95,45\% (sangat layak). Pencapaian rasio jumlah sarana praktik dengan jumlah siswa adalah 2,72\% (sangat tidak layak).
\end{abstract}

Kata Kunci : sarana dan prasarana, praktikum, chasis, pemindah tenaga

\section{PENDAHULUAN}

Perkembangan ilmu pengetahuan dan teknologi yang semakin pesat seiring perkembangan zaman. Perkembangan tersebut harus selaras antara kuantitas dan kualitas. Perkembangan teknologi harus diikuti oleh penguasaan teknologi. Penguasaan teknologi tersebut harus di ikuti oleh masyarakat umum dan para peserta didik. Siswa-siswi Sekolah Menengah Kejuruan (SMK) yang memang disiapkan untuk menjadi calon pegawai industri yang mampu bersaing mengikuti perkembangan zaman (Mulyasa, 2013).

SMK sebagai salah satu instansi pendidikan formal yang diharapkan mampu memberikan kontribusi secara intensif. SMK diharapkan dapat mempersiapkan tenaga kerja yang kompeten pada bidangnya untuk memenuhi kebutuhan industri terhadap tenaga kerja. SMK, terutama siswa harus menyelaraskan antara teori dan Praktik. Penyelarasan antara teori dan praktik adalah salah satu jalan untuk menciptakan lulusan yang kompeten. Teori dan praktik pada hakikatnya tidak dapat dipisahkan untuk penyempurnaan pada penerapan yang akan diaplikasikan di dunia usaha dan industri (Maniarti, 2011).

\footnotetext{
1 Mahasiswa Departemen Pendidikan Teknik Mesin FPTK, UPI

2 Dosen Departemen Pendidikan Teknik Mesin FPTK, UPI

3 Dosen Departemen Pendidikan Teknik Mesin FPTK, UPI
} 
Lulusan Siswa SMK, terutama lulusan SMK Otomotif yang kompeten dihasilkan dari sekolah yang memberikan pendidikan yang memenuhi standar pendidikan Nasional. Pendidikan didalam Undang-Undang No.20 tahun 2003 tentang Sistem Pendidikan Nasional (Sisdiknas) Bab 1 Ketentuan Umum Pasal 1 (1) didefinisikan usaha sadar dan terencana untuk mewujudkan suasana belajar dan proses pembelajaran agar peserta didik secara aktif mengembangkan potensi dirinya untuk memiliki kekuatan spiritual keagamaan, pengendalian diri, kepribadian, kecerdasan, akhlak mulia, serta keterampilan yang diperlukan dirinya, masyarakat, bangsa dan negara.

Pendidikan adalah suatu proses dari satu rangkaian aktivitas yang mengarahkan potensi, peluang individu untuk berasimilasi dan mengembangkan pengetahuan, keterampilan, nilai-nilai dan sikap dan pemahaman yang bukan hanya sekedar menghubungkan teori dengan teori pada suatu wilayah tertentu, akantetapi mesti mencapai jangkauan luas dari permasalahan yang dideskripsikan, diteliti dan dipecahkan (Kuswana, 2013). Undang-undang Sisdiknas No. 20 Tahun 2013 tentang Sistem Pendidikan Nasional Bab IX Standar Pendidikan Nasional Pasal 35 ayat (1), mengemukakan bahwa Stadar Pendidikan Nasional terdiri atas standar isi, proses, kompetensi lulusan, tenaga kependidikan, sarana dan prasarana, pengelolaan, pembiayaan dan penilaian pendidikan yang harus ditingkatkan secara berencana dan berkala.

Sarana dan Prasarana adalah komponen penunjang dalam kegiatan belajar mengajar di Sekolah Menengah Kejuruan (SMK). Sarana dan prasarana pendidikan terdiri dari ruang belajar, tempat berolahraga, tempat beribadah, perpustakaan, laboratorium, bengkel kerja, tempat bermain, tempat berkreasi dan berkreasi, termasuk penggunakan media informasi dan komunikasi, serta sumber belajar lain yang menunjang proses pembelajaran (Kuswana, 2014).

Peraturan Pemerintah Nomor 19 tentang Standar Pendidikan Nasional Bab VII Tentang Standar Sarana dan Prasarana Pendidikan, Undang-undang Nomor 20 Tahun 2003 tentang Sistem Pendidikan Nasional Bab XII Sarana dan Prasarana Pendidikan Pasal 45. Peraturan Menteri Pendidikan Nasional Nomor 40 Tahun 2008 tentang Standar Sarana dan Prasarana Sekolah Menengah Kejuruan dan Madrasah Aliyah.

Hasil dari observasi di bengkel kerja siswa kelas XI di SMK Negeri 6 Bandung. Ditemukan bahwa area kerja chassis dan pemindah tenaga digunakan juga sebagai tempat perletakan imulator-simulator kelistrikan body otomotif. Salah satu ukuran dari ruang kerja, yaitu ruang kerja kelistrikan otomotif belum sesuai dengan Badan Standar Nasional 
Pendidikan. Hasil observasi uas area kelistrikan adalah $8,375 \mathrm{~m}^{2}$ dan lebar 1,34 $\mathrm{m}$.

\section{METODE PENELITIAN}

Penelitian ini merupakan penelitian deskriptif menggunakan pendekatan kuantitatif dengan skala persentase. Penelitian ini menggunakan metode studi kasus melalui survei lapangan. Kasus yang menjadi fokusnya yaitu saktual sarana dan prasarana praktik mata pelajaran pemeliharaan chassis dan pemindah tenaga di SMK N 6 Bandung. Kemudian dibandingkan dengan standar sarana dan prasarana praktik menurut Peraturan Menteri Pendidikan Nasional Nomor 40 Tahun 2008 tentang Standar Sarana dan Prasarana Sekolah Menengah Kejuruan dan Madrasah Aliyah (SMK/MAK).

\section{HASIL PENELITIAN}

Hasil penelitian ini terdiri dari tiga aspek, yaitu: prasarana praktik pada area kerja pemeliharaan chasis dan pemindah tenaga, sarana praktik pada area kerja pemeliharaan chasis dan pemindah tenaga, dan rasio jumlah sarana praktik pemeliharaan chasis dan pemindah tenaga dengan jumlah siswa. Hasil penelitian diperoleh, sebagai berikut:

1. Ruang praktek sebesar $75 \%$;

2. Area praktek sebesar $71 \%$;

3. Alat praktek sebesar $65 \%$;

4. Alat Pelindung Diri (APD) sebesar $80 \%$;

5. Rasio peralatan praktek yang tidak sesuai dengan standar 97,28\%; dan

6. Rasio peralatan praktek yang sesuai dengan standar $2,72 \%$.

\section{PEMBAHASAN}

Aspek yang akan dibahas mengenai sarana dan prasarana praktik pada mata pelajaran pemeliharaan chasis dan pemindah tenaga, yaitu: pencapaian standar prasarana ruang praktik dari 4 yang diteliti, 3 aspek telah memenuhi standar nasional pendidikan. Persentase pencapaian standar prasarana ruang praktik yaitu $75 \%$, dan dikategorikan layak. Pencapaian standar prasarana ruang praktik di SMK Negeri 6 Bandung belum sepenuhnya tercapai. Sarana praktik pada area kerja chasis dan pemindah tenaga belum memenuhi standar. Akantetapi tingkat pencapaian standar sarana pada area praktik dari 7 yang diteliti, 5 aspek telah memenuhi standar nasional pendidikan. Pencapaian standar prasarana ruang praktik yaitu 71,42\%, dan dikategorikan layak (Purwanto dan Sukardi, 2015). 
Pencapaian sarana praktik pemeliharaan sistem koplin belum sepenuhnya tercapai, yaitu sarana praktik pada area kerja chasis dan pemindah tenaga belum memenuhi standar. Pencapaian sarana praktik dari 16 yang diteliti, 11 aspek telah memenuhi standar nasional pendidikan. Pencapaian sarana praktik yaitu 68,75\%, dan dikategorikan layak. Pencapaian sarana praktik pemeliharaan transmisi manual belum sepenuhnya tercapai, yaitu sarana praktik pada area kerja chasis dan pemindah tenaga belum memenuhi standar. Pencapaian sarana praktik dari 23 yang diteliti, 10 aspek telah memenuhi standar nasional pendidikan. Persentase tingkat pencapaian standar prasarana ruang praktik yaitu 43,47\%, dan dikategorikan kurang layak.

Pencapaian sarana praktik pemeliharaan final drive/gardan belum sepenuhnya tercapai. Sarana praktik pada area kerja chasis dan pemindah tenaga belum memenuhi standar. Pencapaian sarana praktik dari 14 yang diteliti, 6 aspek telah memenuhi standar nasional pendidikan. Persentase tingkat pencapaian standar prasarana ruang praktik yaituv42,85 \%, dan dikategorikan kurang layak. Pencapaian sarana praktik pemeliharaan poros roda pada SMK Negeri 6 Bandung belum sepenuhnya tercapai, yaitu sarana praktik pada area kerja chasis dan pemindah tenaga belum memenuhi standar. Tingkat pencapaian sarana praktik dari 13 yang diteliti, 7 aspek telah memenuhi standar nasional pendidikan. Persentase tingkat pencapaian standar prasarana ruang praktik yaitu 53,84\%, dan dikategorikan kurang layak.

Pencapaian sarana praktik pemeliharaan sistem rem belum sepenuhnya tercapai. Sarana praktik pada area kerja chasis dan pemindah tenaga belum memenuhi standar. Pencapaian sarana praktik dari 22 yang diteliti, 17 aspek telah memenuhi standar nasional pendidikan. Persentase tingkat pencapaian standar prasarana ruang praktik yaitu $77,27 \%$, dan dikategorikan layak. Pencapaian sarana praktik pemeliharaan sistem kemudi belum sepenuhnya tercapai. Sarana praktik pada area kerja chasis dan pemindah tenaga belum memenuhi standar. Pencapaian sarana praktik dari 22 yang diteliti, 21 aspek telah memenuhi standar nasional pendidikan. Persentase tingkat pencapaian standar prasarana ruang praktik yaitu 95,45\%, dan dikategorikan sangat layak.

Pencapaian sarana dan prasarana praktik pada mata pelajaran pemeliharaan chasis dan pemindah tenaga dari 110 alat praktik yang diteliti, 72 aspek telah memenuhi standar. Persentase tingkat pencapaian sarana praktik yaitu 65,45 \%, dan dikategorikan layak. Pencapaian APD praktik pada mata pelajaran pemeliharaan chasis dan pemindah tenaga di dari 5 APD yang diteliti, 4 aspek telah tersedia Persentase tingkat pencapaian sarana praktik yaitu $80 \%$, dan dikategorikan layak. 
Pencapaian standar prasarana peralatan praktik pemeliharaan chasis dan pemindah tenaga di SMK Negeri 6 Bandung belum sepenuhnya tercapai. Persentase tingkat pencapaian sarana praktik (Syafrudie, 2004) yaitu: rasio sarana praktik pada pemeliharaan sistem kopling, dari 16 yang diteliti, semuanya tidak memenuhi standar atau dikategorikan sangat tidak layak. Rasio sarana praktik pada pemeliharaan poros roda, dari 23 yang diteliti, hanya 1 yang memenuhi standar. Persentase pencapaian rasio sarana praktik yaitu $4,34 \%$, dan dikategorikan sangat tidak layak. Rasio sarana praktik pada pemeliharaan final drive/gardan, dari 14 yang diteliti, hanya 1 yang memenuhi standar. Persentase pencapaian rasio sarana praktik yaitu 7,14\%, dan dikategorikan sangat tidak layak. Rasio sarana praktik pada pemeliharaan poros roda, dari 13 yang diteliti, hanya 1 yang memenuhi standar. Persentase pencapaian rasio sarana praktik yaitu 0,7\%, dan dikategorikan tidak layak. Rasio sarana praktik pada pemeliharaan sistem rem, dari 22 yang diteliti, tidak ada yang memenuhi standar sehingga dikategorikan tidak layak. Rasio sarana praktik pada pemeliharaan sistem kemudi, dari 22 yang diteliti, hanya 1 yang memenuhi standar. Persentase pencapaian rasio sarana praktik yaitu $4,54 \%$, dan dikategorikan tidak layak.

Rasio antara jumlah sarana praktik dengan jumlah siswa pada mata pelajaran Pemeliharaan Chasis dan Pemindah Tenaga kelas XI TKR di SMK Negeri 6 Bandung. Rasio antara jumlah sarana praktik dengan jumlah siswa, dari 110 yang diteliti, 3 memenuhi standar. Persentase pencapaian rasio sarana praktik yaitu $2,72 \%$, masuk dalam kategori sangat tidak layak.

\section{KESIMPULAN}

Kesimpulan penelitian ini, sebagai berikut: prasarana praktik pada mata pelajaran pemeliharaan chasis dan pemindah tenaga sudah memenuhi standar. Empat area ruang praktek yang diteliti termasuk salah satunya area kerja chasis dan pemindah tenaga, tiga telah memenuhi standar berdasarkan Peraturan Menteri Pendidikan Nasional Nomor 40 Tahun 2008 tentang Standar Sarana dan Prasarana untuk Sekolah Menengah Kejuruan (SMK)/ Madrasah Aliyah Kejuruan (MAK). Kondisi Sarana Praktik pada Mata Pelajaran Pemeliharaan Chasis dan Pemindah Tenaga Program Studi Teknik Kendaraan Ringan di SMK Negeri 6 Bandung layak. Data menunjukkan dari 110 peralatan praktik yang diteliti, 105 sudah ada dan dalam kondisi sangat layak. Rasio perbandingan sarana praktik dengan jumlah siswa pada mata pelajaran pemeliharaan chasis dan pemindah tenaga tidak memenuhi standar, dikategorikan sangat tidak layak. 


\section{REFERENSI}

Kuswana, W. S. (2013). Dasar-Dasar Pendidikan Vokasi \& Kejuruan. Bandung: Alfabeta.

Kuswana, W. S. (2014). Ergonomi dan K3. Bandung: PT Remaja Rosdakarya.

Maniarti, S. (2011). Administrasi dan Manajemen Sekolah. Jogjakarta: Ar Ruzz Media.

Mulyasa, E. (2013). Pengembangan dan Implementasi Kurikulum 2013. Bandung: PT Rosdakarya.

Purwanto dan Sukardi, T. (2015). Pengelolaan Bengkel Praktik SMK Teknik Pemesinan di Kabupaten Purworejo. Jurnal Pendidikan Teknologi dan Kejuruan, 22 (3). hlm.291-306.

Syafrudie, et. al. (2004). Standar Minimal Laboratorium, Workshop, dan Studio Pendidikan Teknologi Kejuruan Jenjang S1. Jakarta: Departemen Pendidikan Nasional. 